\title{
Explicating the Prevalence of Women Farmers' Deterrence from Microfinance Banks (MFBs) Loans in South-East Nigeria. A Censored Tobit Regression Model of Analysis
}

Igwe ikenna UKOHA ( $\square$ igwe.ukoha@futo.edu.ng )

Federal university of technology owerri https://orcid.org/0000-0002-3170-1331

Remy Mejeha

Michael Okpara University of Agriculture

Jude Nwaru

Michael Okpara University of Agriculture

Okwudili lbeagwa

Federal University of Technology Owerri

Ifeanyi Maduike

Federal University of Technology Owerri

Emeka Osuji

Michael Okpara University of Agriculture

\section{Research}

Keywords: Loan deterrence, women, smallholder farmers, MFBs, Agriculture

Posted Date: August 7th, 2020

DOI: https://doi.org/10.21203/rs.3.rs-54432/v1

License: (c) (i) This work is licensed under a Creative Commons Attribution 4.0 International License.

Read Full License 


\title{
Explicating the Prevalence of Women Farmers' Deterrence from Microfinance Banks (MFBs) Loans in South-East Nigeria.
}

\section{A Censored Tobit Regression Model of Analysis.}

\author{
Ukoha, I. I ${ }^{1}$, Mejeha, R.O ${ }^{2}$, Nwaru, J.C ${ }^{2}$, Ibeagwa, O.B ${ }^{1}$., Maduike, I.A ${ }^{1}$.,Osuji, E.E²., \\ ${ }^{1}$ Department of Agricultural Economics, Federal University of Technology Owerri. \\ ${ }^{2}$ Department of Agricultural Economics Michael Okpara University of Agriculture Umudike.
}

Corresponding author: Ukoha, Igwe Ikenna

Igwe.ukoha@futo.edu.ng

\begin{abstract}
The Prevalence of Farmers' Deterrence from loan applications has the technical potential to proliferate, the level of financial exclusion in developing countries. Conversely, assessments of the determinants of the aforementioned practices remain limited. In contrast to erstwhile studies, this paper this fills the research gap by offering specific consideration to a divergent methodology in examining the prevalence of smallholder women farmers' deterrence from MFBs credit, while considering expressions of the premeditated decisions made by the farmers not to apply for loans. Cross-sectional data collected via the administration of questionnaire were further analyzed using the loan deterrence indices model (LDI) and the censored Tobit regression (CTR) model. Evidence from results showed a high prevalence of loan deterrence by the farmers. Furthermore, we find that farm size, age of the respondents, household size, annual income, education level, proximity to bank, and accessibility to account officer are strong drivers of loan deterrence in South-East Nigeria. We recommend that MFBs should make loaning conditions "farmer friendly" by introducing more account officers, educating the farmers on terms and conditions to be met on loan contracts, extending credit to farmers irrespective of their age, farm size and annual income among others.
\end{abstract}

Key words: Loan deterrence, women, smallholder farmers, MFBs, Agriculture.

\section{JEL Classification: B4, D63, G2, J16, J71}

\section{Introduction}

Agribusiness is very vital economic development in several nations globally, principally when considering low income nations which are characterized by the high level dependence on agriculture and agricultural by products as a means of livelihood (Assogba, 2017). In Nigeria and sub Saharan Africa, Agriculture is imperative for a positive transformation and economic development (Bello et al. 2016; Ukoha, 2020). More than $70 \%$ of smallholder farmers in Nigeria depend on agriculture as a source of livelihood thereby making it very important for Nigeria's quest to achieve a number of the objectives within the Sustainable Development Goals SDGs. Unfortunately, food production in this region has not kept the pace with the growing population in decades and it is susceptible to further decrease. To worsen the situation, it is predicted that crops yield in the region will likely decline up to 50 per cent by 2030 (Intergovernmental Panel on Climate Change, 2001). It is anticipated that in future, prosperity of the 
rustic populace in Nigeria ought to be attached to agribusiness. Consequently, encouraging agrarian development can offer a definite pathway out of penury.

A divergence into agribusiness by the Federal Government will be significant for economic development, transferring its advantages to provincial regions, thereby preventing economic stuns from a solitary reliance on oil (NBS, 2010). loans to farmers are well recognized vital instruments for advancing farm yield particularly among smallholder farmers that comprise a high level of the cultivating populace in Nigeria (Nwaru, 2004; Mejeha and Ifenkwe, 2007; Nwaru, 2011). According to (Samareen and Zaidi, 2012), (MFBs) provide micro-credits to low income individuals, and Like every loan, they must be reimbursed. For this reason, the MFBs must assess their client's financial activities as well as the risks of their operations due to the fact that loaning is dicey, and yet beneficial. Dividends and levies on farm credits are wellsprings of benefits to Microfinance banks. Financial institutions won't have any desire to disburse loans to smallholder women farmers who can't reimburse the credit.

Loans to farmers have displayed a serious level of unpredictability in recent times. It waned from N67.74 billion at year 2004 to N49.39 billion at year 2006, increased to N149.57 billion at year 2007, waned again to N106.35 billion in year 2008 which later increased to N135.7 billion by year 2009 (CBN, 2011). This pattern displays components of vulnerability. It was also observed that between years $2004-2008$ only a trivial 4.4 percent was disbursed to farmers (CBN, 2010). Consequently, only a limited number of rural farmers are in a position to meet their financial requirements.

Globally, farmers decide on choices vacillating from the time to sow seeds; using improved innovation and which innovation to grasp; if they should rent additional workers for farming activities; the time to sell the homestead products and furthermore if it will be wise for them to partake in non-ranch monetary exercises, inter alia. There is another significant decision that farmers are confronted with, which happens to be the decision on the need and application for loans.

Though ample research works on issues of borrower deterrence from credit applications are available (Chandler, 2010; Chun, and Mun, 2012; Chakravarty, and Xiang, 2013), there are very limited studies on the prevalence of loan deterrence and secondly most of the studies aren't gender sensitive and also not related to smallholder farmers. Due to the communal backgrounds of farmers and the need for smallholder agribusiness financing in Nigeria, there is a staggering need to reevaluate the issue of the prevalence of loan deterrence (PLD) from MFBs amongst the female smallholder farmers. All around, researchers are beginning to develop an acknowledgment for significance in gender fairness on problems relating to farmers accessibility to agricultural loans. Truth be told, most global consultations and contemporary studies have recognized this reality. Providing agricultural loans to smallholder farmers in a timely and farmer friendly manner while avoiding women discrimination is one of such basic strategies that will encourage smallholder farmers in need for agricultural loans to make applications so as to break the vicious cycle of poverty, expand their farming business and increase their income.

According to (Jeiyol, Akpan, and Tee, 2013), farming has been considered by the vast majority as a manly controlled activity. In any case, according to the UNDP, (2003) results from an empirical examination, uncovered that female smallholder farmers account for around 60-80\% of farm work population in Nigeria, although it depends on the agricultural zone, of which $66 \%$ of the output is being expended in Nigeria.

The idea that the gender of the farmer is a strong factor influencing agricultural credit disbursement due to loan discrimination by most banks is well acknowledged in academic and policy literatures (Marlow and Patton, 2005). According to Watson, (2006), women smallholder farmers are known for cultivating farm produce strictly for household consumption, spending time attending to the needs of their progenies, 
doing household chores, lacking resourcefulness, having low competence in risk management and of the general sensitivity that the will be discriminated against, by financial institutions. Consequently deterrence from loan application by smallholder women farmers is expected. The occurrence of borrower deterrence has gotten little attention from banks and policy makers.

Most publications on agricultural finance restrictions, has either omitted farmers deterred from loan applications from financial evaluations or joined them with improper group of loan applicants for example, rejected loan applicants. According to Cole, (2010); Hernández-Cánovas, Ramón-Llorens, and Koëter-Kant (2014), it is noteworthy to differentiate between deterred and rejected loan applicants when conducting a research on loan disbursement by financial institutions.

In addition, recent agricultural financing publications have seen farmers access to loans or financial restrictions in Nigeria sub Saharan Africa commonly centered uniquely around the farmers who really apply for credit (Jeiyol, Akpan, and Tee 2013; Ajagbe, 2012; Ukoha, Orebiyi, and Eze, 2013; Nwaru, Essien, and Onuoha 2011; Sebu 2013; Sebu 2017). According to Sebu (2013) these empirical works inter alia, have concentrated on farmers who succeeded in receiving the credit and also farmers whose loan applications were denied while others studies have taken a gander at the sources of credit for farmers and its utilization. In some cases, policies and recommendations from the research findings from this works are subsequently unfit to affect family units that are deterred from applying for loans even when it is needed.

The objective of this research work is to divulge an extra insight into the perplexing inquiry of the prevalence of loan deterrence (PLD) from MFBs amongst the female smallholder farmers. Bearing in mind the predisposition in these examinations, it is important to incorporate smallholder farmers who remain deterred from applying for loans. This paper consequently considers, smallholder women farmers who need credit despite the fact that it's very essential for the modernization and expansion of their farm business but are however disheartened in light of the fact that the dread that their applications will be turned down.

\section{Literature review}

\section{1 loan deterrence}

According to Ukoha, (2020) farmers' deterrence from loan applications are broadly regarded as farmers who need loans and however, decide not to make their interest known to the bank based on some reasons: Previous applications were turned down, previous loans were rationed by the banks, scarcity of security requirement, high application costs, stressful procedure (bureaucracy), dislike the idea of being known as debtors, do not have a bank account, inter alia, other than not in need for the loans.

Stiglitz and Weiss (1981) have contended that due to the presence of information asymmetry, banks will continue to ration loans even in situations where we have market equilibrium. Credit institutions don't have all data on the entirety of their clients hence the utilize some screening strategies, for example, growing the rates of interest or loan costs and security prerequisites to identify prospective defaulters. The possible outcome of this bank decisions include the following; Firstly, loan applicants may acquire short of what they at first anticipated; Secondly, a few loan applicants might be turned down or out rightly rejected by the bank; And finally, both creditworthy and non-creditworthy loan applicants might be deterred from further loan applications. Only very few research works on credit accessibility have incorporated deterred loan applicants. Reasons why majority of studies do exclude the deterred loan applicants is because they don't make any advance application and might be on the grounds that they don't add to bank advance portfolio hazard. Be that as it may, an assessment on deterred loan applicants have become vital as a result the primary reasons given above (Han, Fraser and Storey 2009). Deterred loan 
applicants are well-known to be twice as much as rejected loan applicants (Freel, Carter, Tagg and Mason, 2012).

According to (Kon and Story, 2003) deterrence from loan applications is assumed to be a self-rationing practice where the loan applicants don't indicate their interest in loans based on their self-evaluation, which makes them to be considered as a non-creditworthy group by the banks. Sebu (2013) recognized deterred loan applicants as potential customers who have a high probability of rejection and do not have any significant bearing for credit in light of the impression of being prevented due to the unfavorable cost of loan applications. Kon and Story (2003) anyway confine the definition to financially trustworthy organizations in his assessment of deterred borrowers. This was done since all banks attempt to abstain from loaning to credit defaulters. Recent assessments on deterred borrowers have for the most part centered on small non- agribusiness ventures and more than half of the studies were carried out in advanced nations, (Brown, Ongena, Popov, and Yeşin, 2011). This leaves a tremendous wide margin when these research works are done in developing countries who consider smallholder farmers as the drivers of their economies.

\section{Materials and methods}

\subsection{Study Area}

This study was examined in the South-east agro-ecological region of Nigeria region encompasses five states specifically: Abia state, Anambra state, Ebonyi state, Enugu state and Imo State. The region has a population of $16,381,729$ people which is about $30 \%$ of the national population comprising of Abia State; $2,845,380$ people with 1,430,298 males and 1,415,082 females, Imo state; 3,927,563 people with 1,976,471 males and 1,951,092 females Anambara State has 4,177,828 people with 2,117,984 males and 2,059,844 females, Enugu state has 3,267,837 people while Ebonyi State has 2,176,947 (National Population Commission Nigeria 2017). The South-east agro-ecological region has the second largest number of microfinance banks in the country with a 19.4\% share and a total number of 169 microfinance banks, comprising of; Anambara 75, Imo 38, Abia 25, Ebony 8 and Enugu 23 microfinance. The decisions to carry out this research in the South-east agro-ecological region of Nigeria are as follows viz: the intense financial relationship between smallholder farmers and microfinance banks, secondly, the toplevel socio-cultural homogeneity as the dwellers are for the most part Igbos, known principally for their cultivating exercises and economic dexterity and finally, the scarcity of empirical work done on borrowers deterrence from loan applications.

\subsection{Sampling Technique}

Multiphase sampling procedure was adopted for sample selection. In the first phase, 2 states of the 5 states in the south-east were purposively selected namely, Imo and Enugu states respectively based on predominance of female smallholder farmers and also the presence of large number of microfinance banks. In the second phase, three Agro-ecological regions from each of the chosen States were selected for the study. From Enugu state, Enugu zone, Nsukka zone, and Awgu zone, were purposively nominated from the six agro-ecological regions based on the presence of microfinance banks from each LGA. From Imo State, Owerri Zone, Orlu Zone and Okigwe Zone were purposively selected based on the presence of microfinance banks from each LGA. In the third phase, one Local Government Area (LGA) was chosen from each state, namely, Enugu -Nsukka, Isi Uzo ,and Ani LGAs; Imo - Owerri, Orlu and Okigwe LGAs, which gives us six (6) LGAs. Additionally, at the fourth stage, we purposively selected three communities of which the decision was centered on the existence of microfinance banks from each LGA, bringing the total number of selected communities to eighteen (18). In the fifth stage, (12) women farmers were selected through snowball technique (a technique whereby smallholder who is deterred from loan applications serves as a link to other deterred loan applicants), from each of the 18 communities to give a total of (216) respondents who were deterred from loan applications. However, out of the (216) respondents sampled for the purpose of this research, only (180) respondents could provide valid and 
complete information for further research. These (180) women constituted the sample size of the survey. We made use of data from primary sources. The questionnaire was structured in the form as to meet the solutions to the objective of the study. This segment of the questionnaire confined, among others, four principle inquiries on which this research is focused.

1) In the past 5 farming seasons how many times have you been in need for farm credit?

2) How many times did you apply for MFBs loans

3) How many times were you discouraged from loan application from MFBs loans in the last 5 farming seasons and what were your major reasons for being deterred

4) For what reason did you not endeavor to acquire over the most recent farming season

\subsection{Analytical Techniques}

\subsubsection{Loan deterrence indices for smallholder women farmers}

In ascertaining the prevalence of loan deterrence (PLD) and also factors influencing the PLD from MFBs amongst the female smallholder farmers, the loan deterrence indices model (LDI) and the censored Tobit regression model was used. The loan deterrence indices was determined by the formula,

$L D I_{i}=\frac{T N T D A L}{T N T I L}$

Where;

$\boldsymbol{L} \boldsymbol{D} \boldsymbol{I}_{\boldsymbol{i}}=$ loan deterrence indices of the $\mathrm{i}^{\text {th }}$ smallholder female farmer

TNTDAL $=$ Total number of times a farmer is deterred from applying for a loan even when he/she is in need for a loan.

TNTIL= Total number of times a farmer has been in need for a loan (measured as the sum of the times a farmer is willing to apply for a loan and when he/she is discouraged from applying for a loan).

From the model, LDI indicates the prevalence of loan deterrence (PLD) status of the farmers and ranges from zero to one. Indices closer to one indicate farmers that are more deterred from loan application, while indices farther from one indicate farmers who are less discouraged from loan application. An index of one indicates perfect loan deterrence. The maximum likelihood estimation of the Tobit regression was used in line with Asogwa, Okwoche and Umeh (2012) and Olagunju and Ajiboye (2010). Following the methodology of Etim, and Patrick (2010), we applied the Tobit model in ascertaining the effect of the regressors on the probability of the PLD from MFBs amongst the female smallholder farmers. From the methodologies of Okwoche and Umeh (2012) the model presumes that most variables have a lower (or upper) limit and take on this limiting value for a substantial number of respondents. For the remaining respondent, the variables take on a wide range of values above (or below) the limit. The regressand happens to be the loan deterrence indices indicated by the LDI, which was censored at zero. According to Nto, (2016), the Tobit methodology safeguards the degrees of freedom making it appropriate in this study where our regressors have a continuous impact on the regressand. Due to the fact that the loan deterrence indices can never have a negative sign, (having a zero threshold), therefore the regressand is written using an index function methodology which is being expressed based on (Tobin 1958; Asogwa, Okwoche and Umeh 2012; Nto 2016) as;

$\mathrm{V}_{\mathrm{i}}^{*}=\beta^{\mathrm{T}} \mathrm{X}_{\mathrm{i}}+u_{i}$

$\mathrm{V}_{\mathrm{i}}=0$ if $\mathrm{V}_{\mathrm{i}}^{*} \leq 0$

$\mathrm{V}_{\mathrm{i}}=\mathrm{V}_{\mathrm{i}}^{*}$ if $\mathrm{V}_{\mathrm{i}}^{*}>0$

$\mathrm{i}=1,2$.

According to Nto (2016) 
$\mathrm{V}_{\mathrm{i}}$, symbolizes a limited regressand, which concurrently estimates the probability of loan deterrence.

$\mathrm{V}_{\mathrm{i}} *$ is an fundamental latent variable which indexes level of loan deterrence.

$\mathrm{X}$ is the vector of the regressors influencing the probability of loan deterrence.

$\beta^{\mathrm{T}}$ is a vector of parameters to be estimated.

$u_{i}$ is the residual term.

When $\mathrm{V}_{\mathrm{i}}{ }^{*}>0$, the farmer is considered to be less deterred from loan application. Otherwise, if $\mathrm{V}_{\mathrm{i}}{ }^{*} \leq 0$ the farmer is considered to be more deterred from loan application. Therefore, the value of the LOG likelihood function is specified as:

$\boldsymbol{L D I} \boldsymbol{I}_{\boldsymbol{i}}=\mathrm{f}\left(\mathrm{X}_{1}, \mathrm{X}_{2}, \mathrm{X}_{3}, \mathrm{X}_{4}, \mathrm{X}_{5}, \mathrm{X}_{6}, \mathrm{X}_{7}, \mathrm{X}_{8}, \mathrm{X}_{9}, \mathrm{X}_{10}, \mathrm{X}_{11} u\right)$

Where;

$\boldsymbol{L D} \boldsymbol{I}_{\boldsymbol{i}}=$ Loan deterrence Index

$\mathrm{X}_{1}=$ Farm size (hectares)

$\mathrm{X}_{2}=$ Age of the farmer (years)

$\mathrm{X}_{3}=$ House hold size (No. of people eating from the same catering arrangement)

$\mathrm{X}_{4}=$ Annual farm income (Naira)

$\mathrm{X}_{5}=$ Education level (Years)

$\mathrm{X}_{6}=$ Farming experience (years)

$\mathrm{X}_{7}=$ Proximity to bank $(\mathrm{km})$

$\mathrm{X}_{8}=$ Number of banks in location (Number)

$\mathrm{X}_{9}=$ Accessibility to account officer (D; $1=$ Accessible (attended to $>4$ times yearly), $0=$ otherwise)

$\mathrm{X}_{10}=$ Off-Farm income (Naira)

$\mathrm{X}_{11}=$ Membership of corporative (Dummy D; $1=$ member, $0=$ otherwise)

$u_{i}=$ residual / disturbance term

\section{Results and Discussion}

The result of the censored Tobit regression model used to ascertain the factors influencing female smallholder farmers who are deterred from loan applications is presented in Table 1

The distribution of the smallholder women farmers by loan deterrence indices along is presented in Table 1.

Table 1: The loan deterrence indices of smallholder women farmers

\begin{tabular}{lcc}
\hline Loan discouragement index & \multicolumn{2}{c}{ Female } \\
& Frequency & $\%$ \\
\hline $0.25-0.34$ & 16 & 8.9 \\
$0.35-0.44$ & 19 & 10.6 \\
$0.45-0.54$ & 45 & 25.0 \\
$0.55-0.64$ & 60 & 33.3 \\
$0.65-0.74$ & 20 & 11.1 \\
$0.75-0.84$ & 14 & 7.8 \\
$0.85-0.94$ & 6 & 3.3 \\
Total & 180 & 100 \\
Mean & 0.559 & \\
\hline
\end{tabular}

\section{Source: Computed by the researcher from field survey data, 2019}

From Table 1, the mean loan deterrence index for female smallholder farmers is 0.559 . This finding suggests that for every 10 times the female farmers were in need for a loan to enhance their agricultural activities they were deterred from applying for such loan need from microfinance banks in the area at 
least 6 times. Majority (33.3\%) of the female farmers were deterred from applying for a loan at most 6 times out of every 10 times they were in need for a loan. The result showed that loan discouragement for smallholder farmers in southeast Nigeria is high. It may also be that female smallholder farmers are more desperately in need for loans and are more deterred to continue applying with expectation of rejection.

Table 2: Censored Tobit regression result of the factors influencing the prevalence in loan deterrence (PLD) from MFBs amongst the female smallholder farmers

\begin{tabular}{lcccc}
\hline Variables & Coefficient & Std. Error & z-statistic & Prob. \\
\hline Constant & 3.135 & 0.720 & $4.351^{* * *}$ & 0.000 \\
Farm size (hectares) & 1.371 & 0.350 & $3.919^{* * *}$ & 0.000 \\
Age of the farmer (years) & 1.368 & 0.581 & $2.355^{* *}$ & 0.033 \\
House hold size & 1.500 & 0.680 & $2.205^{* *}$ & 0.046 \\
Annual income (Naira) & 1.296 & 0.408 & $3.178^{* * *}$ & 0.000 \\
Education level (years) & 0.817 & 0.206 & $3.972^{* * *}$ & 0.000 \\
Farming experience (years) & -1.548 & 2.016 & -0.768 & 0.000 \\
Proximity to bank (kilometers) & 0.992 & 0.406 & $2.443^{* *}$ & 0.049 \\
Number of banks in location & -1.174 & 1.760 & -0.667 & 1.063 \\
Accessibility to account officer & -0.032 & 0.010 & $-3.303^{* * *}$ & 0.000 \\
Off-Farm income (Naira) & 1.296 & 1.236 & 1.048 & 0.308 \\
Membership of cooperative & -0.927 & 0.947 & -0.979 & 0.611 \\
Pseudo R-square & 0.885 & & & \\
Log- Likelihood & -1432.129 & & & \\
\hline Source: Fin & & &
\end{tabular}

Source: Field survey data, 2019

$* * *$ significant at $1 \%$; ** significant at $5 \%$ and $*$ significant at $10 \%$.

From the maximum likelihood estimates of the Tobit regression the results show that the model fits the data realistically and suitably. This indicates that amongst all the conceivable regression lines, the coefficients maximizes the joint probability of observing the $n$ sample values of the female farmers being deterred from credit applications. This specifies that variations in female farmers prevalence in loan deterrence (PLD) from MFBs credit in the study area is explicated by the estimates of the regressors, indicating that the model explicates a significant non-zero discrepancies on the drivers of the prevalence in loan deterrence from MFBs. Additionally, results revealed that the Pseudo R-square was 0.885, which makes the censored Tobit regression model a very good fit for the data thereby explicating $88.5 \%$ discrepancy in prevalence in loan deterrence from MFBs is explicated by discrepancies on the stated regressors, and hence a confirmation that the censored Tobit model possesses a strong explicatory influence on variations in the prevalence in loan deterrence from MFBs amongst the smallholder women farmers.

The coefficients of farm size, age of the respondents, household size, annual income, education level, proximity to bank, and accessibility to account officer are the statistically significant factors that influenced the PLD from MFBs amongst the female smallholder farmers.

The coefficient of farm size had a negative sign and also significant at $1 \%$, indicating that possession of large farm size decreases the probability of the PLD from MFBs amongst the female smallholder farmers. Hence increases in farm size might lead to a decrease in the probability of the PLD from MFBs amongst the female smallholder farmers. Female farmers with vast farm holdings tend to be less discouraged than those with smaller holdings due to the fact that vast farm sizes are projected to generate additional net- income, which would facilitate their loan application approvals. The findings are in agreement with Sebu, (2013) who was of the view that a vast farm size might be associated to farmers' affluence. Smallholder women farmers who possess vast farm sizes could harvest more yields indicating reasons for the PLD. 
The coefficient of age of the respondents is positive and also significant at $1 \%$ thereby indicating that the older the female smallholder farmers, the greater the probability their PLD from MFBs. According to the CBN (2005) regulatory guidelines, only clients of MFBs that fall within the age bracket of 18 and 60 years shall be eligible for credit. This agrees with the results of Chitungo, and Munongo (2013) who observed that the older the farmer, the more the returns to experience disappear hence the farmers output diminishes drastically making their demand for credit to drop significantly. Sebu (2013) was of the opinion that when a farmer gets old he gains more understanding of the farming business and wealthier. Therefore the need for credit is naturally predictable for younger farmers. (Freel et al., 2012).

Household size had a positive coefficient and was also significant at $1 \%$, which implies increase in the population of their household sizes leads a higher probability of the PLD from MFBs amongst the female smallholder farmers. There is a general perception that smallholder farmers are known to have low income and large household sizes (Sebu, 2013). With evident burden of destitution within smallholder farming communities, female farmers who have more dependents might require additional funds to guarantee a better standard of living hence loan deterrence will be evident due to the fact that poor households lack the means to acquire assets which can serve as securities for loans

The coefficient of annual farm income of smallholder female farmers was positive and also significant at $1 \%$, suggesting that high annual farm income of the farmers increases the probability in their prevalence of loan deterrence from MFBs. Increase in annual farm income will avail more investment capital to the farmers and will reduce their desire to apply for credit. This finding is consistent with the Ogbonna (2016) who observed that increase in farm income increases the equity capital for investment of a farmer and decreases the desire for debt financing overtime.

The coefficient of education level attained by the female smallholder farmers was negative and also significant at $1 \%$ thereby indicating that female smallholder farmers with lower levels of education attained, had a higher probability in the prevalence in loan deterrence from MFBs than their counterparts who have attained higher education levels. Education is a great incentive towards understanding loan application criteria. According to Hananu et al., (2015) and Assogba et al. (2017), it will be very difficult for farmers to understand the credit scheme of banks and also their terms and conditions if they do not have basic education. Hence it justifies the negative influence of formal education on farmers deterrence to loan applications. In addition the result is in agreement with the opinions of Akudugu (2012) and Dzadze et al., (2012) that the need for credit to expand and modernize their farm business is subdued by farmers' low level of education attainment.

The coefficient of proximity to the bank was positive and significant at $5 \%$ level. This suggests that the closer the distance from the locality of farmers to MFBs the higher the probability of the PLD from MFBs amongst the female smallholder farmers. This observation appears counter intuitive due to the fact that smallholder farmers that dwell very far from MFBs within their locality will need to trek several miles to the banks or spend more money on transportation to the banks thereby adding to their level of inconvenience and frustration hence their deterrence from loan applications. But this result could be an implication that women who reside close to the banks reside in more urban settlements which serves as a proxy for higher income while women who reside further away are rural dwellers, probably have lower income and hence the need for more credit.

The coefficient of accessibility to account officer was negative and significant at $1 \%$. This suggests that the more inaccessible a farmer is to the account officer, the higher the probability of the PLD from MFBs amongst the female smallholder farmers. The closer a farmer is to his/her account officer the better his/her relationship with the officer. This can serve as an incentive to the farmer towards getting a quicker loan approval. This is because the account officer will guide the farmer on how to apply for a loan, look through his farm cash flow and enlighten the farmer on how much to apply for easy approval and how to avoid the cumbersome process of getting a loan facility. Account officers plays a vital role in guiding loan 
applicants on the terms involved in taking a bank loan and this helps to reduce the cumbersomeness in getting a loan facility.

\section{Conclusion.}

This finding recommends that agricultural finance studies carried out on credit exclusion should include deterred borrowers so as to ensure that farmers who are credit constrained are fully investigated for proper policy decisions.

Specific policies and programmes geared towards resolving all the problems contributing to borrower discouragement of the female smallholder farmers will go a long way in actualizing the dream of getting female farmers willing and able to expand and modernize their farm business thereby increasing farm production levels and ameliorating the incidence of poverty across the country and the entire globe.

MFBs should make the loaning conditions farmer friendly by introducing more account officers, educating the farmers on terms and conditions to be met on loan contracts, extending credit to farmers irrespective of their age farm size and annual income among others. Likewise, the federal government and the financial institutions cooperate effectively so as to stimulate agribusiness so as to create more employment and break the vicious cycle of poverty.

Finally, agricultural packages and guidelines which can improve the microfinance banks' lending to farmers should be adopted so as to efficiently motivate smallholders who are the drivers of economic growth.

\section{Acknowledgements}

Not applicable.

\section{Authors' contributions}

Ukoha, I. I., Mejeha, R.O., Nwaru, J.C., Ibeagwa, O.B., Maduike, I.A.,Osuji, E.E., agreed on the research content. Ukoha, I. I., Ibeagwa, O.B., Maduike, I.A.,Osuji, E.E collected all the data for analysis Ukoha, I. I., Mejeha, R.O., Nwaru, J.C completed the analysis based on agreed steps. Results and conclusions are discussed and written together. All authors read and approved the final manuscript.

\section{Funding}

No funding is used.

\section{Availability of data and materials}

The datasets used and analyzed during the current study are available from the corresponding author on request.

\section{Competing interests}

The authors declare that they have no competing interests.

Author details

${ }^{1}$ Department of Agricultural Economics, Federal University of Technology Owerri.

${ }^{2}$ Department of Agricultural Economics Michael Okpara University of Agriculture Umudike.

\section{References}

Ajagbe F. A., (2012). Analysis of Access to and Demand for Credit by Small Scale Entrepreneurs. Evidence from Oyo State, Nigeria. Journal of Emerging Trends in Economics and Management Sciences. Volume 3(3):180-183. 
Akudugu, M. A. (2012): "Estimation of the Determinants of Credit Demand by Farmers and Supply by Rural Banks in Ghana's Upper East Region", Asian Journal of Agriculture and Rural Development, Vol. 2, No. 2, pp. 189-200.

Assogba P.N., Kokoye S.E.H., Yegbemey, R.N., Djenontin, A.J. (2017). Determinants of credit access by smallholder farmers in North-East Benin. Journal of Development and Agricultural Economics Vol. 9(8), pp. 210-216, DOI: 10.5897/JDAE2017.0814

Bello, T.A Balogun, O.L Afodu, O.J Akinboye, O.E Ndubusi-Ogbonna, L.C Shobo, B.A (2016) Determinants Of Productivity Of Rice Farmers In Ogun State Nigeria. Researchjournali's Journal of Agriculture. Vol. 3 No. 4 www.researchjournali.com

Brown, M., Ongena, S., Popov, A. and Yeşin, P. (2011). Who needs credit and who gets credit in Eastern Europe? Economic Policy, 26, 93-130.

Central Bank of Nigeria (2005).Microfinance policy Regulatory and Supervisory Framework for Nigeria.https://www.cbn.gov.ng/OUT/PUBLICATIONS/GUIDELINES/DFD/2006/REGULATO RY\%20GUIDELINES.PDF

Central Bank of Nigeria (2010).Economic and Financial Review Volume.48/4, Pp 41.

Central Bank of Nigeria. (2014). Annual report.

Chitungo, S.K., and Munongo, S. (2013) Determinants of farmers' decision to access credit: the case of Zimbabwe. Russian Journal of Agricultural and Socio-Economic Sciences, 5(17) Pages 7-12

Chakravarty, S. and Xiang, M. (2013). The international evidence on discouraged small businesses. Journal of Empirical Finance 20, 63-82.

Chandler, V. (2010). An interpretation of discouraged borrowers based on relationship lending. Small Business and Tourism Branch, Industry Canada. Government of Canada.

Chitungo S. K and Munongo, S. (2013) Extending the Technology Acceptance Model to Mobile Banking Adoption in Rural Zimbabwe, Journal of Business Administration and Education, Vol. 3, No. 1, , pp. 57-79.

Chun, H., and Mun, S. (2012). Determinants of R\&D cooperation in small and medium-sized enterprises. Small Business Economics 39(2), 419-436. Cole, Rebel A. (2010). Who needs credit and who gets credit? Evidence from the surveys of small business finance. MPRA working paper 24691.

Cole, Rebel A. (2010). Who needs credit and who gets credit? Evidence from the surveys of small business finance. MPRA working paper 24691.

Cole, Rebel A. (2013) what do we know about the capital structure of privately held US firms? Evidence from the surveys of small business finance. Financial Management 42 (4), 777-813.

Dzadze, P., Mensah, O. J., Aidoo, R., Nurah, G.K. (2012). Factors determining access to formal credit in Ghana: A case study of smallholder farmers in the Abura-Asebu Kwamankese district of central region of Ghana. Journal of Development and Agricultural Economics Vol. 4(14), pp. 416-423

Etim, N.A.A. and I.V. Patrick, (2010). Estimating the determinants of poverty among fishing households in Akwa Ibom State, Nigeria. J. Agric. Soc. Sci., 6: 61-63 
Freel, M., Carter, S., Tagg, S. \& Mason, C. (2012). The latent demand for bank debt: characterizing "discouraged borrowers". Small Business Economics, 38, 399-418.

Han, L., Fraser, S. \& Storey, D. J. (2009). Are good or bad borrowers discouraged from applying for loans? Evidence from US small business credit markets. Journal of Banking \& Finance, 33, 415424.

Hananu B, Abdul-Hanan A, Zakaria H (2015). Factors influencing agricultural credit demand in Northern Ghana. Afr. J. Agric. Res. 10(7):645-652.

Hernández-Cánovas, G., Ramón-Llorens, M.C., Koëter-Kant, J (2014) A demand approach to borrower discouragement: Empirical analysis in a bank-based economy. XII Finance Forum. Saragossa.

Intergovernmental Panel on Climate Change (2001). Climate Change 2001: Synthesis Report. A Contribution of Working Groups I, II and III to the Third Assessment Report of the Intergovernmental Panel on Climate Change. Watson, R. T. and the Core Writing Team, eds. Cambridge, UK: Cambridge University Press.

Jeiyol E N., Akpan, S. B and Tee, T.N (2013) Gender Analysis of Access to Credit by Rural Small Scale Farmers in Benue State Nigeria. American International Journal of Social Science Vol. 2 No. 6

Kon, Y. and Storey, D. J. (2003). A Theory of Discouraged Borrowers. Small Business Economics, 21, $37-49$

Marlow, S., and Patton, D. (2005). All credit to men? Entrepreneurship, finance and gender. Entrepreneurship Theory and Practice, 29, pp. 717-736

Mejeha, R. O., and Ifenkwe, G. E. (2007). Density and microfinance service coverage of rural banks in Nigeria. International Journal of Agriculture and Rural Development. 10 (2), 1-6.

National Population Commission Nigeria. (2017). preliminary revised population projections. Abuja, Nigeria: National Population Commission.

Nto, P. O.O (2016). Assessment of Risk in the Internally Generated Revenue (IGR) Structure of Abia State, Nigeria. Canadian Social Science, 12 (3), 67-72. Available from: http:// www.cscanada.net/index.php/css/article/view/8177 DOI: http://dx.doi.org/10.3968/8177

Nwaru J. C, Essien U. A, Onuoha R.E., (2011). Determinants of Informal Credit Demand and Supply among Food Crop Farmers in Akwa Ibom State. Nigeria Journal of Rural and Community Development, 6, 1; 129-139

Nwaru, J. C. (2004). Rural credit markets and resource use in arable crop production in Imo State of Nigeria. An unpublished Ph.D. Dissertation, Michael Okpara University of Agriculture, Umudike, Nigeria.

Nwaru, J. C. (2011). Determinants of informal credit demand and supply among food crop farmers in Akwa Ibom state, Nigeria journal of rural and community development ISSN: 1712-8277. Journal of rural and community

Samreen, A., and Zaidi, F.B (2012) Design and development of credit scoring model for the commercial banks of pakistan: Forecasting creditworthiness of individual borrowers International Journal of Business and Social Science Vol. 3 No. 17 Pp155-166 
Sebu J. (2013). Farm Households' Access to Credit: who needs and who gets? Evidence from Malawi. University of Kent.

Sebu, J. (2017) Essays on farm household credit constraint, productivity and consumption inequality in Malawi. An unpublished Doctor of Philosophy (PhD) thesis, University of Kent.

Stiglitz, J. E. \& weiss, A. (1981). Credit Rationing in Markets with Imperfect Information. The American Economic Review, 71, 393-410.

Ukoha, I. I (2020). A Gender-Based Assessment of Smallholder Farmers' Credit Rationing, Creditworthiness and Distribution by Microfinance Banks in South-East Nigeria. An Unpublished Ph. D. Thesis, Michael Okpara University of Agriculture Umudike, Nigeria

Ukoha, I. I., Orebiyi, J. S., Eze, C. C., Henri-Ukoha, A., Nwaiwu, I. O. U. (2013) Loan Default by Smallholder Farmers in Imo State: Review Process, Recovery Strategies and Preventive Measures. International Journal of Applied Research and Technology. Vol. 2, No. 8, August 2013. $34-41$.

UNDP, (2003).Development of a Sustainable Pro-poor Financial Sector; Phase II Micro Start Nigeria. http://www.uncdf.org accessed 20th January 2012.

Watson, J. (2006). External funding and firm growth: Comparing female and male-controlled SMEs. Venture Capital, 8, 33-49. 